\title{
The Synergy of Lampung Provincial Marine and Fishery Services with Muara Tabulih Fisheries in West Coast District in Protection of Turtle Habitat
}

\author{
Aisyah Muda Cemerlang \\ Criminal Law \\ Lampung University \\ Lampung, Indonesia \\ aisyah.cemerlang@fh.unila.ac.id
}

\author{
Heni Siswanto \\ Criminal Law \\ Lampung University \\ Lampung, Indonesia \\ heni.siswanto@fh.unila.ac.id
}

\author{
Sri Riski \\ Criminal Law \\ Lampung University \\ Lampung, Indonesia \\ sri.riski@fh.unila.ac.id
}

\begin{abstract}
Indications of the failure of green turtle protection are shown by the high exploitation of green turtles in various parts of Indonesia, the decrease in the number of turtles landing on nesting beaches, and the low level of community support. The threat of extinction of green turtles is increasingly real if the government does not immediately stop the exploitation of green turtles. To save green turtles from extinction, it is necessary to analyze the protection policies and formulate alternative protection for green turtles in the future. Analysis of the green turtle protection policy is carried out on the conservation activities of the Marine and Fisheries Service. The results of the policy analysis are needed to learn about the effectiveness of protection and management performance of green turtles in the formulation of alternative protection for sea turtles. The Indonesian government through related agencies, such as the Office of Marine Affairs and Fisheries, the Indonesian Institute of Sciences, and the Ministry of Environment have issued several regulations and policies for the protection of endangered species, such as Ratification of the United Nations Convention on Biodiversity through Law No. 5 of 1994, the ratification of the Convention on International Trade in Endangered Species through Presidential Decree No. 43 of 1978; Stipulation of Government Regulation No. 7 of 1999 and Government Regulation No. 8 of 1999. Stipulation of Government Regulation No. 7 of 1999 has protected green turtles along with 236 species of animals and 58 other plant species in the territory of Indonesia.
\end{abstract}

Keywords-Habitat protection, Turtle, Lampung Province.

\section{INTRODUCTION}

Since 1999 the exploitation of green turtles is an illegal activity. Endangered species status and grouping in Appendix I - CITES and the stipulation of Government
Regulation no. 7 of 1999 made the green turtle a state asset managed by the government. Indonesia's participation in various international conventions CITES in 1978 [1], Ramsar in 1991 [2], and Biodiversity in 1994 [3]. the government appointed the Directorate General of Forest Protection and Nature Conservation of the Ministry of Forestry as the flora and fauna authority management. Green turtle management is based on Law no. 5 of 1990, Government Regulation no. 7 of 1999, and Government Regulation No. 8 of 1999 as a species conservation activity of the Directorate General of PHKA, Ministry of Forestry.

Turtles are iconic organisms that live in marine waters. This is because there are only 7 species of turtles in the world. Turtles are marine reptiles such as tortoises that can explore the world with all four leg fins. Indonesia is one of the nesting habitats for 6 turtles out of 7 turtles in the world. This is because Indonesian waters are a migration route for Sea Turtles at the intersection of the Pacific and Indian Oceans.

The green turtle is one of the sea turtle species capable of migrating across 80 countries. Along the migration path in both tropical and sub-tropical waters, green turtles are exploited except in the Atlantic Oceans Zone. The results of the study about 32 nesting sites around the world reported a $48 \%$ to $67 \%$ decline in the green turtle population over three generations [4]. From the results of the estimation of the green turtle population, the green turtle is then classified as an endangered species. Unlike the case in Indonesia, which is located in the Indian Ocean and Southeast Asia, the decline in the green turtle population is on average $80 \%$. The Red Data Book-IUCN explains that if the population decline of a species reaches $80 \%$ for 
10 years or three generations, the species is classified as a critically endangered species.

The cause of the drastic population decline is confirmed by Bachelor Putra, that the highest exploitation of green turtles in the world is in the territory of Indonesia. The high level of exploitation carried out by the community Generally, brood fishing occurs in the high seas and egg harvesting around the spawning coast. If the capture of broodstock and overharvesting of turtle eggs and continues for decades will result in the extinction of the population. Compared to the other five types of sea turtles, green turtles are the most intensively exploited because their meat and eggs are favored by coastal communities. The high demand for green turtles is due to several reasons ranging from household consumption, sources of community income, customary interests to sources of Regional Original Income. Likewise, the turtle trade system with high transaction costs is still ongoing as a black market in the Tanjung Benoa area of Bali.

\section{TYPES AND RESEARCH METHOD}

The approach to the problem in legal research is determined and limited by the scientific tradition that develops in legal science, which according to Bruggink is based on existing ideas (denkbeelden) and approaches (in the sense that it is limited by the scientific tradition in which legal scientists are located), or in Kuhn's terminology, by prevailing paradigms in legal science Bruggink (1999) [5]. According to Marzuki (2005), the first step of this research is based on doctrinal research using a statute approach, an analytical approach, and a conceptual approach. The data collection technique used is the documentation [6]. Legal materials are collected through procedures for identification, inventory, and classification of legal materials according to research problems. Then the legal materials/data are recorded or cited using a card system.

\section{RESULTS AND DISCUSSION}

Indonesia is known as an archipelagic country with high biodiversity. Most of Indonesia's marine waters (> $51,000 \mathrm{~km}^{2}$ ) are located in the triangle of coral reefs with the highest diversity in the world. The existence of thermocline currents from the Pacific Ocean and the richness of marine life make Indonesian waters important for the wandering of 25 species of marine mammals and six species of sea turtles. Throughout their life sea turtles move from one place to another. Sea turtle migration is a natural phenomenon to fulfill biological needs, such as: looking for food, resting, finding a mate, mating, and getting a nesting location. This periodic movement of sea turtles is capable of traveling thousands of kilometers across the ocean and national borders.

Alternative green turtle protection is directed at habitat protection. An alternative formulation of green turtle protection in Muara Tambulih Village, Pesisir
Barat Regency because it has green turtle nesting areas in Sumatra, as an important roaming area in migration routes and there has been a severe decline in the green turtle population by $>90 \%$ over the last five decades. Conserving and protecting turtles will restore populations and reduce the threat of human exploitation. If several green turtle habitats throughout Indonesia are made into Marine Conservation Areas, then the protection of green turtles is widespread and effective in the form of a network of Marine Protected Areas.

The protection of green turtles implemented by the government has not shown results. Since being designated as a protected animal in 1999, the green turtle population has experienced tremendous pressure from humans in the form of catching broodstock in marine waters, harvesting eggs on nesting beaches, and destroying habitat.

Habitat protection gets international support through The United Nations Convention on the Law of the Sea (UNCLOS) and the Convention on Biological Diversity (CBD). In UNCLOS article 9 chapter 5 it is stated that the state is obliged to protect rare and easily damaged ecosystems which are the habitats of species that are declining in population, threatened and endangered, and another biota from pollution. Article 8 of the CBD states that the establishment of a system of protected areas or areas that require biodiversity conservation. The Preamble of the CBD states that the basic requirements for biodiversity conservation are insitu conservation of ecosystems and natural habitats, as well as the maintenance and restoration of populations of species that can breed in their natural environment.

In-situ conservation is the protection of a species' habitat to reduce the loss of natural habitat and the cause of species extinction in the IUCN (2003) [7]. According to Balmford et al (1996) that in-situ conservation is the most effective and cost-efficient consideration in stopping the rate of population decline [8].

Efforts to conserve turtles need to be carried out as early as possible because for now, the beach where turtle nesting is located is experiencing very severe damage. The damage is a lack of public awareness and the lack of government's role in socializing the importance of efforts to maintain turtle habitat in the turtle conservation area in Pekon Muara Tembulih, Ngambur District, Pesisir Barat Regency, for example, there are still many people who find turtle eggs around the conservation area but not returned to captivity but taken for sale or consumption. As a result, the population of turtles in nature has decreased from day to day, even all types of turtles are included in the extinct category. Conservation efforts that are often carried out are semi-natural hatching. Eggs from natural nests are transferred to sandy buckets. Then the eggs in buckets are brought to a semi-natural hatchery and then planted. 
Turtle population is a collection of individuals of the same species that can breed and are in the same place and at the same time. The green turtle is one of the sea turtle species capable of migrating across 80 countries. Along the migration path in both tropical and sub-tropical waters, green turtles are exploited except in the Atlantic

Oceans Zone. The results of the study about 32 nesting sites around the world reported a $48 \%$ to $67 \%$ decline in the green turtle population over three generations. From the results of the estimation of the green turtle population, the green turtle is then classified as an endangered species. Unlike the case in Indonesia, which is located in the Indian Ocean and Southeast Asia, the decline in the green turtle population is on average $80 \%$. The Red Data BookIUCN explains that if the population decline of a species reaches $80 \%$ for 10 years or three generations, the species is classified as a critically endangered species.

The high level of exploitation carried out by the community Generally, brood fishing occurs in the high seas and egg harvesting around the spawning coast. If the capture of broodstock and overharvesting of turtle eggs and continues for decades will result in the extinction of the population. Compared to the other five types of sea turtles, green turtles are the most intensively exploited because their meat and eggs are favored by coastal communities. The high demand for green turtles is due to several reasons ranging from household consumption, sources of community income, customary interests to sources of Regional Original Income (PAD). Likewise, the turtle trade system with high transaction costs is still ongoing as a black market in the Muara Tembulih Pekon area, Ngambur District, Pesisir Barat Regency.

Law No. 5 of 1990, Government Regulation no. 7 of 1999, and Government Regulation No. 8 of 1999 as a species conservation activity of the Directorate General of PHKA, Ministry of Forestry. Indications of the failure to protect green turtles are shown by the high exploitation of green turtles in various parts of Indonesia, a decrease in the number of turtles landing on nesting beaches, and low community support. The threat of green turtle extinction is getting more real if the government does not immediately stop the exploitation of green turtles. To save green turtles from extinction, it is necessary to analyze protection policies and formulate alternative protections for green turtles in the future.

\section{CONCLUSIONS AND SUGGESTION}

Protection of turtle habitat in Muara Tambulih Village, Ngambur sub-district, Pesisir Barat Regency, there are still many obstacles or problems faced related to the implementation of its activities so that it does not run as it should. Problems or obstacles were found such as the lack of good coordination and communication from policy implementers, lack of supervision from the Lampung Province Maritime Affairs and Fisheries Service regarding the implementation of policies implemented in the field. And the lack of budget from the Department of Maritime Affairs and Fisheries of Lampung province in the context of protecting the turtle habitat in Muara Tambulih Village, Ngambur District, Pesisir Barat Regency.

\section{REFERENCES}

[1] Based on the laws and regulations, the leatherback turtle species are protected based on the Decree of the Minister of Agriculture No.327/Kpts/Um/5/1978; loggerhead turtle and Lekang are protected by SK Minister of Agriculture No.716/Kpts/Um/10/1980; Hawksbill and Flat Turtles are protected by decree Minister of Forestry No.882/Kpts-II/1992, and Green Turtle which is included in 6 types of turtles that are protected by PP No.7/1999 on preservation plants and animals.

[2] Convention on Wetlands of International Importancem Especially as Waterfowl Habitat, 1991

[3] Shahid Naeem, Lindsey J. Thompson, Sharon P. Lawler, John H. Lawton \& Richard M. Woodfin,Declining biodiversity can alter the performance of ecosystems, Cite this article. 1994

[4] Muhammad Irfan Afif and Fredinan Yulianda,Analysis of Ecobiology of Green Sea Turtle (Chelonia mydas) and its Threatening factors in Citirem and Hujungan Coasts, Cikepuh Wildlife Reserve, Sukabumi, Indonesia, Jurnal Pengelolaan Perikanan Tropis, Juni 2020, Volume 4 Nomor 1. 2020

[5] Bruggink J.J.H. Refleksi tentang Hukum, Citra Aditya Bakti, 1999.

[6] Marzuki, Metodologi Riset, Yogyakarata: Ekonisia. 2005

[7] Chen ES, et al. Cti1/C1D interacts with condensin SMC hinge and supports the DNA repair function of condensin. Proc Natl Acad Sci U S A 101(21):8078-83. 2004

[8] Balmford, Andrew. "Extinction filters and current resilience: the significance of past selection pressures for conservation biology." Trends in Ecology \& Evolution 11.5 (1996): 193196. 